\title{
REMOVING ARSENIC, COPPER AND IRON FROM SEWAGE SLUDGE WITH REED (Phragmites australis)
}

\author{
Cortés-Torres, C. ${ }^{1}$ - BARRIENTOS-LOZANO, L. ${ }^{1}$ - Almaguer-SiERra, P. ${ }^{1}$ - Rosas-MeJíA, \\ $\mathrm{M}^{2}{ }^{2}$ - ROCANDIO-RODRÍGUEZ, M. $^{2}-$ AlARCÓN, A. ${ }^{3 *}-$ MORA-RAVELO, S. G. ${ }^{2 *}$ \\ ${ }^{I}$ División de Estudios de Posgrado e Investigación, Tecnológico Nacional de México-Instituto \\ Tecnológico de Cd. Victoria, Blvd. Emilio Portes Gil No. 1301, 87010 Cd. Victoria, \\ Tamaulipas, México
}

${ }^{2}$ Universidad Autónoma de Tamaulipas, Instituto de Ecología Aplicada, Av. División del Golfo núm. 356, Col. Libertad, 87019 Cd. Victoria, Tamaulipas, México

${ }^{3}$ Colegio de Postgraduados, Carretera México-Texcoco km.36.5, Montecillo, Texcoco 56230, Edo de México, México

*Corresponding authors

e-mail:ssmora@docentes.uat.edu.mx; alexala@colpos.mx

(Received $2^{\text {nd }}$ Jan 2019; accepted $28^{\text {th }}$ Feb 2019)

\begin{abstract}
Agriculture can use the sewage sludge resulting from wastewater treatment. In order to use sewage sludge, it is necessary to eliminate the content of toxic pollutants, including heavy metals through phytoremediation. The purpose of this research work was to assess the capacity of Phragmites australis to remove $\mathrm{As}, \mathrm{Cu}$ and $\mathrm{Fe}$ in wastewater sludge of the municipal treatment plant in Cd. Victoria, Tamaulipas. We established four treatments: $\mathrm{T} 1$ = sewage sludge + soil + Phragmites australis; $\mathrm{T} 2=$ sewage sludge + soil; $\mathrm{T} 3=$ Sludge + Phragmites australis; $\mathrm{T} 4=$ Check test. Each treatment had six replicates. The phytoremediation process lasted eight months. We took monthly samples from the substrate and samples of $P$. australis every four months to determine the contents of $\mathrm{As}, \mathrm{Fe}$ and $\mathrm{Cu}$. The sludge + soil $+\mathrm{P}$. australis treatment was able to remove higher percentages of $\mathrm{Fe}(96.63 \%)$ and $\mathrm{Cu}(47.67 \%)$; while sludge + P. australis was able to remove higher percentage of arsenic (81.18\%), with a bio-concentration factor of 7.76. The amount of metals removed from the substrates from highest to lowest were: $\mathrm{Fe}>\mathrm{Cu}>\mathrm{As}$. Furthermore, the final concentration of $\mathrm{Fe}, \mathrm{Cu}$ and Arsenic in the sludge was below the allowable limit established by NOM-004- SEMARNAT-2002 Standard.
\end{abstract}

Keywords: bio-concentration factor, heavy metals, Phytoremediation, translocation factor

\section{Introduction}

Wastewater treatment is a worldwide strategy to recover water contaminated by residential and industrial use. The process does not only produce treated water, but also suspended solids known as sewage sludge or bio-sludge (Jing et al., 2017). Sewage sludge is treated and biologically stabilized to avoid harming living creatures and the environment. Once stabilized, sewage sludge turns into bio-solids used in fertilization, crop enhancement, forest remediation, composting and power generation (Castañeda et al., 2011; CRA, 2000).

Like other countries, Mexico has implemented wastewater treatment programs since 2008, including PROTAR (Wastewater Treatment Program), aiming to increase the volume of treated water and improve existing treatment processes. Thanks to these projects, the number of operating wastewater treatment plants in the country increased to 2447 by December 2015, representing an installed capacity of $177973.58 \mathrm{~L} \mathrm{~s}^{-1}$. Nevertheless, those plants treat only $120902.20 \mathrm{~L} \mathrm{~s}^{-1}$ of wastewater, leaving behind 2911234 t year $^{-1}$ of bio-solids (CONAGUA 2015). CONAGUA (2011) reported that 
$37 \%$ of the treated wastewater streams produce 640,000 to 10 million $\mathrm{t}^{\text {year }}{ }^{-1}$ of biosolids. This difference is because sometimes the quantity is reported in terms of dry weight and in other cases the moisture content is not even mentioned; so in fact, there is no official data regarding sewage sludge and bio-solids production, and therefore, the percentage of treated bio-sludge is very low.

Sewage sludge obtained from wastewater treatment does not only have a high level of nutrients, but also several pollutants, such as heavy metals. The presence of trace elements transforms sewage sludge in a source of environmental pollution. The gases released when the sludge breaks down produce a fetid odor coming from a large number of fecal coliforms, including some pathogens like Salmonella spp., and elements that are toxic in high concentrations. It is therefore important to treat sewage sludge and eliminate, reduce or form compounds that will not harm living organisms and the environment (Rojas and Mendoza 2012).

Stabilizing sewage sludge from wastewater plants implies very high operating costs. Phytoremediation is a solution to this problem, offering an effective, low-cost in situ solution. Wetlands retain trace elements in a natural way, in particular Typha latifolia L. and $P$. australis Cav. Trin. (Salema et al., 2014).

The cost of conventional stabilization and reuse of sewage sludge is unaffordable at Cd. Victoria, Tamaulipas' wastewater treatment plant. Therefore, untreated sludge is disposed inside the plant facilities, becoming a source of environmental pollution. This research work is aiming to determine Phragmites australis' capacity to remove arsenic, copper and iron from sewage sludge produced by Ciudad Victoria, Tamaulipas' wastewater treatment plant.

\section{Materials and methods}

The experiment was conducted from May 2015 to January 2016 at the hydroponic module of Ciudad Victoria's Technology Institute (ITCV).

$500 \mathrm{~kg}$ of untreated sewage sludge were collected at Cd. Victoria, Tamaulipas' wastewater treatment plant and taken to ITVC facilities to fill $19 \mathrm{~kg}$-pots which were used as individual experimental units, using a $5-\mathrm{cm}$ gravel bed for planting and propagating $P$. australis. We established four treatments, each one with six replicates; 24 experimental units in total (Table 1).

We collected $P$. australis spikes from San Marcos River banks, Cd. Victoria, Tamaulipas. We selected the thicker spikes with the largest number of nodes for propagation. We made diagonal cuts every three nodes, in order to propagate the cuttings in every experimental unit. We organized the experimental units at random and we planted three cuttings in each experimental unit, watering them with drinking water. The experiment lasted eight months under uncontrolled conditions at an average temperature of $26^{\circ} \mathrm{C}$. We took monthly samples of the substrate $(30 \mathrm{~g})$ close to the roots and we selectted one plant per treatment every four months, to determine the concentration of $\mathrm{As}, \mathrm{Cu}$ and $\mathrm{Fe}$ on the substrate and on $P$. australis. (The first sampling was in September).

\section{Substrate characteristics}

Table 1 shows the soil and sludge initial characteristics. The initial $\mathrm{pH}$ of soil and the sewage sludge was slightly acidic and had a small increase after mixing both substrates. As and $\mathrm{Cu}$ concentrations were lower than the maximum allowable limits of 41- 
$75 \mathrm{mg} \mathrm{kg}^{-1}$ and $1500-4300 \mathrm{mg} \mathrm{kg}^{-1}$ respectively in dry weight, according to NOM-004SEMARNAT-2002 standard.

Table 1. Initial characteristics of the waste sludge, soil and the mixture of both substrates

\begin{tabular}{c|c|c|c}
\hline Parameter & Sludge & Soil & Sludge + soil \\
\hline $\mathrm{As}\left(\mathrm{mg} \mathrm{kg}^{-1}\right)$ & 1.61 & 0.283 & $1.893^{*}$ \\
$\mathrm{Cu}\left(\mathrm{mg} \mathrm{kg}^{-1}\right)$ & 12.411 & 1.29 & $13.701^{*}$ \\
$\mathrm{Fe}\left(\mathrm{mg} \mathrm{kg}^{-1}\right)$ & 656.365 & 5.839 & $662.204^{*}$ \\
$\mathrm{pH}$ & 6.780 & 6.750 & 6.990 \\
$\mathrm{CE}\left(\mathrm{dS} \mathrm{m}^{-1}\right)$ & 4.360 & 1.855 & 1.030 \\
$\mathrm{PR}(\mathrm{mV})$ & -50.2 & -45.9 & -39.7 \\
$\mathrm{MO}(\%)$ & 5.414 & 1.083 & 1.963 \\
$\mathrm{Nt}(\%)$ & 1.072 & 0.142 & 0.389 \\
$\mathrm{P}\left(\mathrm{mg} \mathrm{kg}^{-1}\right)$ & 33.161 & 1.005 & 15.576 \\
$\mathrm{~K}\left(\mathrm{cmol}_{(+)} \mathrm{kg}^{-1}\right)$ & 0.189 & 0.492 & 0.082 \\
\hline
\end{tabular}

$\mathrm{CE}=$ Electrical conductivity, $\mathrm{Nt}=$ total nitrogen, $\mathrm{ORP}=$ redox potential

*For the case of the mixture, the concentrations of $\mathrm{As}, \mathrm{Cu}$ and $\mathrm{Fe}$ were not determined, so the value presented here is an approximation, based on the initial concentration of the metals in the waste sludge and the soil

Heavy metals' determination: We analyzed the substrate and P. australis samples to determine the content of metals using inductively coupled plasma atomic emission spectroscopy (ICP-OES Varian model 725-ES, Agilent, Mulgrave, Australia).

\section{Data analysis}

The bio-concentration factor (BFC) (Chandra, 2013), was calculated using Equation 1:

$$
B F C=\frac{c_{p}}{c_{i}}
$$

where: $C_{i}=$ initial metal concentration in the substrate, and $C_{p}=$ metal concentration in the plant.

The translocation factor (TF) (Chandra, 2013) was determined by Equation 2:

$$
T F=\frac{c_{a}}{c_{r}}
$$

where: $C_{a}=$ metal concentration in aerial plant parts and $C_{r}=$ metal concentration in plant roots.

$\mathrm{pH}$ and reduction-oxidation potential (PR) results were analyzed by linear regression, to determine their dependency. Metal concentrations in the substrates were submitted to repeated measures analysis of variance and Fisher's LSD test $(p<0.05)$. We analyzed metal concentrations, $\mathrm{BCF}$ and $\mathrm{TF}$ of the plants by discrimination functions, in order to determine the difference among these variables. Finally, we applied a canonical correlation to find the relation between metal concentrations in the plant and the 
substrates. We conducted the statistical analysis of the variables with PROC REG, MIXED, DISCRIM and CANCORR procedures, using SAS software (2002) and Statistica, version 7.

\section{Results}

The high temperatures in $\mathrm{Cd}$. Victoria $18.5-31{ }^{\circ} \mathrm{C}$ dehydrated the substrates, reducing their initial volume. We had to add $12 \mathrm{~kg}$ more of sewage sludge to the experimental units in June and September in order to maintain the ratios that were originally proposed for each treatment (we determined the concentration of $\mathrm{As}, \mathrm{Cu}$ and $\mathrm{Fe}$ in the sludge before the addition). The sewage sludge added during those months had lower concentrations of the three metals, than the initial concentrations of $\mathrm{As}, \mathrm{Cu}$ and $\mathrm{Fe}$ found in the original substrates used for the experimental units (Table 2).

Table 2. Concentration of $A s, C u$ and Fe in waste sludge and irrigation water

\begin{tabular}{c|c|c|c}
\hline Sample & $\mathbf{A s}\left(\mathbf{m g ~ k g}^{\mathbf{- 1}}\right)$ & $\mathbf{C u}\left(\mathbf{m g ~ k g} \mathbf{~}^{\mathbf{- 1}}\right)$ & $\mathbf{F e}\left(\mathbf{m g ~ k g}^{\mathbf{- 1}}\right)$ \\
\hline Sludge initial & 1.61 & 12.411 & 656.365 \\
Sludge july & 0.000001 & 1.01 & 318.032 \\
Sludge september & 0.000001 & 1.143 & 270.181 \\
Water sample irrigation & 0.034 & 0.088 & 0.021 \\
\hline
\end{tabular}

Only two, out of three plants that we planted in the experimental units survived. During the eight months that the experiment lasted, the plants showed phenotypic differences. Plants with sludge $+P$. australis had more foliage in the aerial parts; while plants growing on the sludge and soil $+P$. australis mix were taller.

We measured the $\mathrm{pH}$ and the reduction-oxidation potential (PR) in the samples of each substrate, four months after planting. The $\mathrm{pH}$ increased from 6.7 to 8.3 , and significant differences were found in the correlation of $\mathrm{pH}$ with time $\left(\mathrm{R}^{2}=0.307\right.$ and $p<0.05)$ and $\mathrm{PR}\left(\mathrm{R}^{2}=0.312\right.$ and $\left.p<0.05\right)$. This parameter changed from -39.7 to 101.4 (Fig. 1).
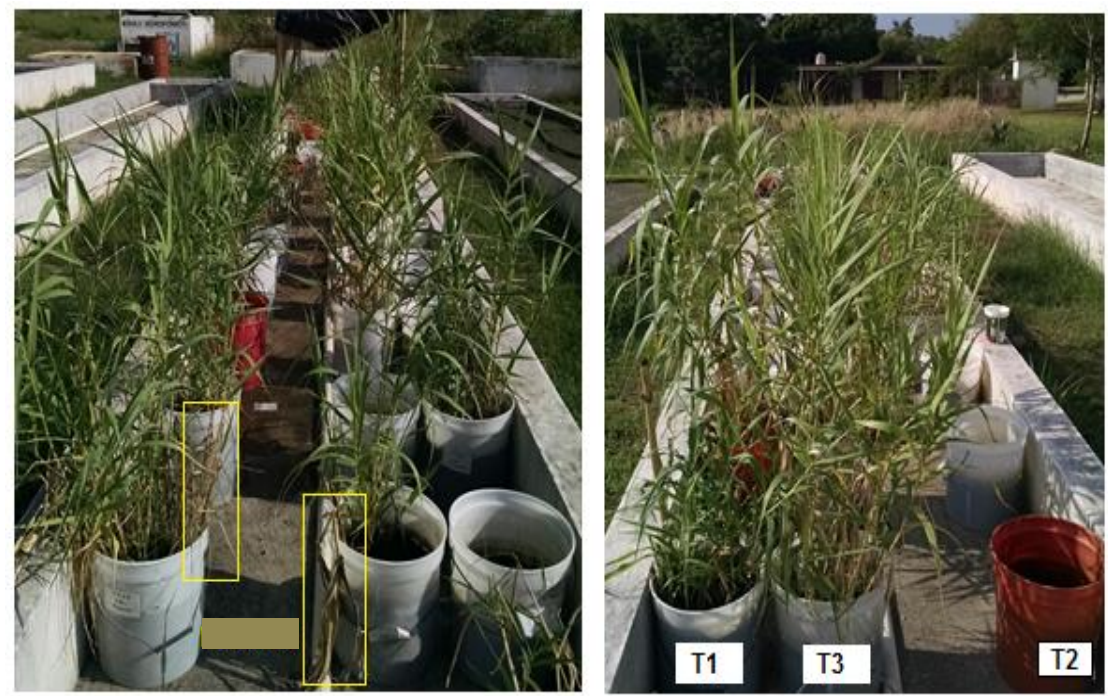

Figure 1. Plants of $P$. australis three months after sowing in the pots. $T 1=$ sewage + soil $+P$. australis, $T 2=$ sewage + soil, $T 3=$ sewage $+P$. australis 
We found significant differences in Arsenic concentration in the substrates throughout the eight months $(\mathrm{F}=2.43$ and $p<0.05)$. The higher concentration was in May, with $1.61 \mathrm{mg} \mathrm{kg}^{-1}$ and the lowest concentration was in November $\left(0.08 \pm 0.06 \mathrm{mg} \mathrm{kg}^{-1}\right)$. There were significant time differences among treatments $(\mathrm{F}=$ 2.74 and $p<0.05$ ). In the second month (June) the sludge and soil $+P$. australis treatment had the highest concentration $\left(0.86 \pm 0.51 \mathrm{mg} \mathrm{kg}^{-1}\right)$, while the lowest concentration was found in October $\left(0.10 \pm 0.24 \mathrm{mg} \mathrm{kg}^{-1}\right)$. The sludge + soil treatment had the highest concentration in July $\left(0.44 \pm 0.38 \mathrm{mg} \mathrm{kg}^{-1}\right)$ and the lowest in November $\left(0.11 \pm 0.06 \mathrm{mg} \mathrm{kg}^{-1}\right)$. The sludge $+P$. australis treatment had the highest concentration in September $\left(0.56 \pm 0.46 \mathrm{mg} \mathrm{kg}^{-1}\right)$ and the lowest in November $\left(0.11 \pm 0.10 \mathrm{mg} \mathrm{kg}^{-1}\right)$. The check test (Sludge) had the highest concentration in August $\left(1.04 \pm 0.72 \mathrm{mg} \mathrm{kg}^{-1}\right)$ and the lowest in November $\left(0.08 \pm 0.05 \mathrm{mg} \mathrm{kg}^{-1}\right)$ (Fig. 2a). The sludge and soil $+P$. australis treatments, as well as the check test showed significant differences $(\mathrm{t}=0.74$ and $p=0.0449)$.
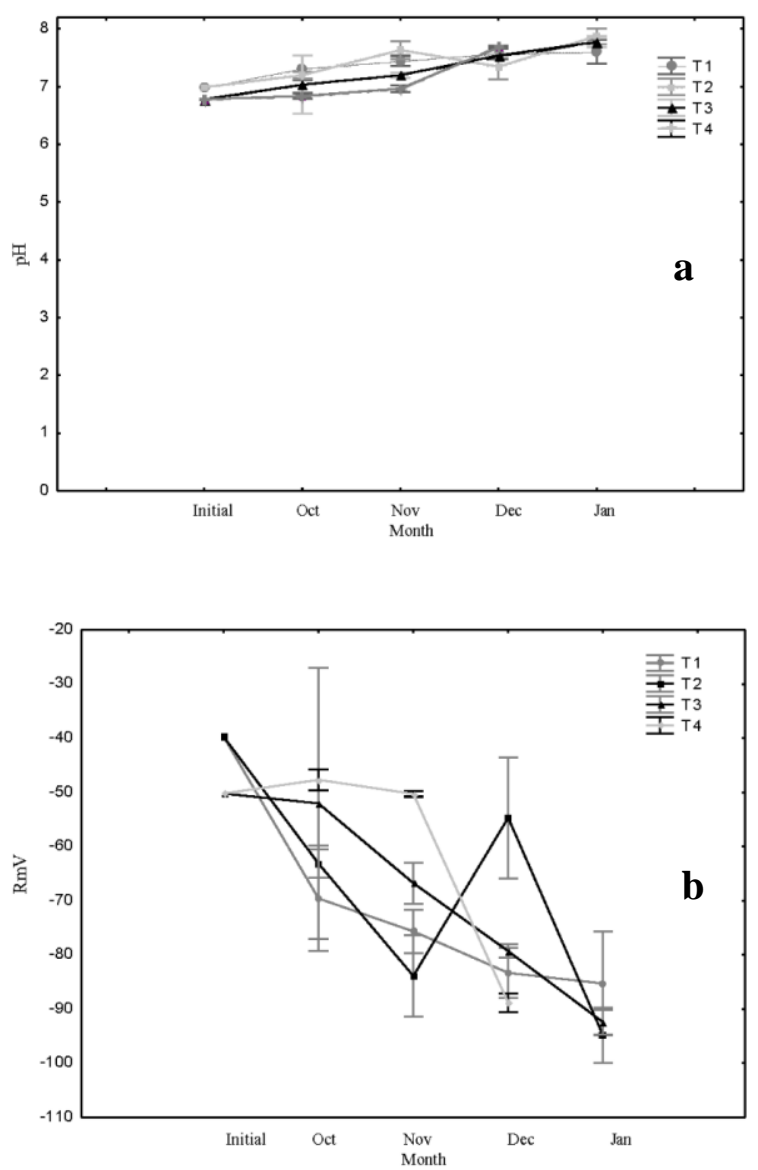

Figure 2. Average values of a) $p H$ and $b$ ) $P R$ with SD bars, during the last four months of the phytoremediation process, for the treatments, $T 1=$ sewage + soil $+P$. australis, $T 2=$ sewage + soil, $T 3=$ sewage $+P$. australis and $T 4=$ sewage, $(n=6)$ with confidence interval of \pm 0.95

$\mathrm{Cu}$ concentration in all treatments had significant differences throughout the months $(\mathrm{F}=7.09$ and $p<0.05)$. The highest concentration was in May $12.41 \mathrm{mg} \mathrm{kg}^{-1}$ and the lowest was in December $\left(3.42 \pm 2.34 \mathrm{mg} \mathrm{kg}^{-1}\right)$. The treatments had significant time differences $(\mathrm{F}=3.06$ and $p<0.05)$, (Fig. 2b). LSD analysis showed that there are 
significant differences in the sludge and soil $+P$. australis mix, and the check test $(\mathrm{t}=2.92$ and $p<0.05)$; as well as between the sludge + soil and the mix sludge and soil $+P$. australis $(\mathrm{t}=4.06$ and $p<0.05)$.

The mg kg${ }^{-1}$ of $\mathrm{Fe}$ showed significant differences throughout the months $(\mathrm{F}=44.98$ and $p<0.05$ ), with lower concentrations switching from one month to another, until reaching a final concentration $\left(14.19 \mathrm{mg} \mathrm{kg}^{-1}\right)$ lower than the initial concentration $\left(656.36 \mathrm{mg} \mathrm{kg}^{-1}\right)$. There were also differences among treatments and among the months $(\mathrm{F}=13.25$ and $p<0.05)$, (Fig. $2 c)$. LSD analysis proved that there were significant differences among the four treatments with $p<0.05$.

The percentage of Arsenic removal from the substrates did not show significant differences among the months and the treatments $(\mathrm{F}=0.89$ and $\mathrm{F}=0.61$ respectively; $p \geq 0.05$ ). We defined a range of 73-83\% in the eight months and in the four treatments. We found significant differences among the months for $\mathrm{Cu}$ removal percentage; however, there were no differences among the treatments $(\mathrm{F}=2.72, p<0.05 ; \mathrm{F}=2.07$, $p \geq 0.05)$. The treatments did not show significant differences on $\mathrm{Fe}$ removal percentage $(\mathrm{F}=3.38, p<0.05 ; \mathrm{F}=2.98, p \geq 0.05)$. We determined the overall removal percentage during the eight months in the four treatments, showing a higher value for Arsenic in the sludge $+P$. australis treatment, as well as for $\mathrm{Cu}$ and $\mathrm{Fe}$ in the mix of sludge and soil + P. australis (Table 3).

Table 3. Summary of the analysis of discriminant functions

\begin{tabular}{c|c|r|r|r|r|r|r|c}
\hline \multirow{2}{*}{ \% Removal } & \multicolumn{9}{|c}{ Treatment } \\
\cline { 2 - 9 } & \multicolumn{2}{|c|}{ SSP } & \multicolumn{2}{c}{ SS } & \multicolumn{3}{c}{ SP } & \multicolumn{3}{c}{ S } \\
\hline As & 80.18 & \pm 3.74 & 80.78 & \pm 3.09 & 83.67 & \pm 9.08 & 73.67 & \pm 6.75 \\
Cu & 47.67 & \pm 10.41 & 31.08 & \pm 6.47 & 42.30 & \pm 11.75 & 23.11 & \pm 11.09 \\
Fe & 96.63 & \pm 2.32 & 87.15 & \pm 3.05 & 83.88 & \pm 4.64 & 76.48 & \pm 2.48 \\
\hline
\end{tabular}

\section{Accumulation of As, Cu and Fe in P. australis}

Metal concentration in P. australis organs was the following: As: 0.07- 1.96, $\mathrm{Cu}$ : 0.92-28.7 and Fe: $121.13-10224.01 \mathrm{mg} \mathrm{kg}^{-1}$ in dry weight. The discrimination analysis found significant differences among the plant parts, regarding the accumulation of heavy metals $[\mathrm{F}=6.2994$, Wilks' Lambda $=0.00019, p<0.05)]$ (Table 4). We found differences in Arsenic concentration in the stem, and $\mathrm{Cu}$ concentration differences in the leaves (Fig. 3). There was a significant difference of $p=0.1129$ at different times, in the sludge and soil $+P$. australis and sludge $+P$. australis mix treatments.

Estimated $\mathrm{BCF}$ values for $\mathrm{Cu}$ and $\mathrm{Fe}$ in the sludge and soil $+P$. australis and the sludge $+P$. australis mix treatments on September and January were greater than 1 ; while for As, the values were greater than 1 in September, and they were lower than 1 in January. TF for As was greater than 1 in the two samplings, on the sludge and soil $+P$. australis and sludge $+P$. australis mix treatments; while TF was below 1 for $\mathrm{Cu}$ and $\mathrm{Fe}$ (Table 5). BCF value was higher in Fe accumulation and lower in As with P. australis. The opposite happened with TF value, which was higher in Arsenic and lower in Fe (Fig. 4). Results of the discrimination function analysis showed that there were no significant differences among the months and the treatments regarding the $\mathrm{BCF}$ values for $\mathrm{Cu}$ and $\mathrm{Fe}(\mathrm{F}=1.4780$, Wilks' Lambda $=0.15692, \mathrm{p}=0.1697)$. The only significant difference for BCF was Arsenic $(p<0.001)$ (Fig. 5). 
Table 4. Summary of the analysis of discriminant functions

\begin{tabular}{c|c|c|c|c}
\hline & Wilks' & Partial & F-remove & p-level \\
\hline \multicolumn{5}{c}{ Root } \\
\hline Cu & 0.000726 & 0.261807 & 469.935 & 0.064384 \\
\hline \multicolumn{5}{c}{ Stem } \\
As & 0.002895 & 0.065653 & 2.371 .949 & 0.002196 \\
Fu & 0.000377 & 0.504194 & 163.894 & 0.293155 \\
\hline \multicolumn{5}{|c}{ Sueet } \\
As & 0.000456 & 0.417124 & 232.895 & 0.191443 \\
Cu & 0.000323 & 0.587784 & 116.884 & 0.408722 \\
Fe & 0.000598 & 0.317606 & 358.093 & 0.101736 \\
\hline
\end{tabular}
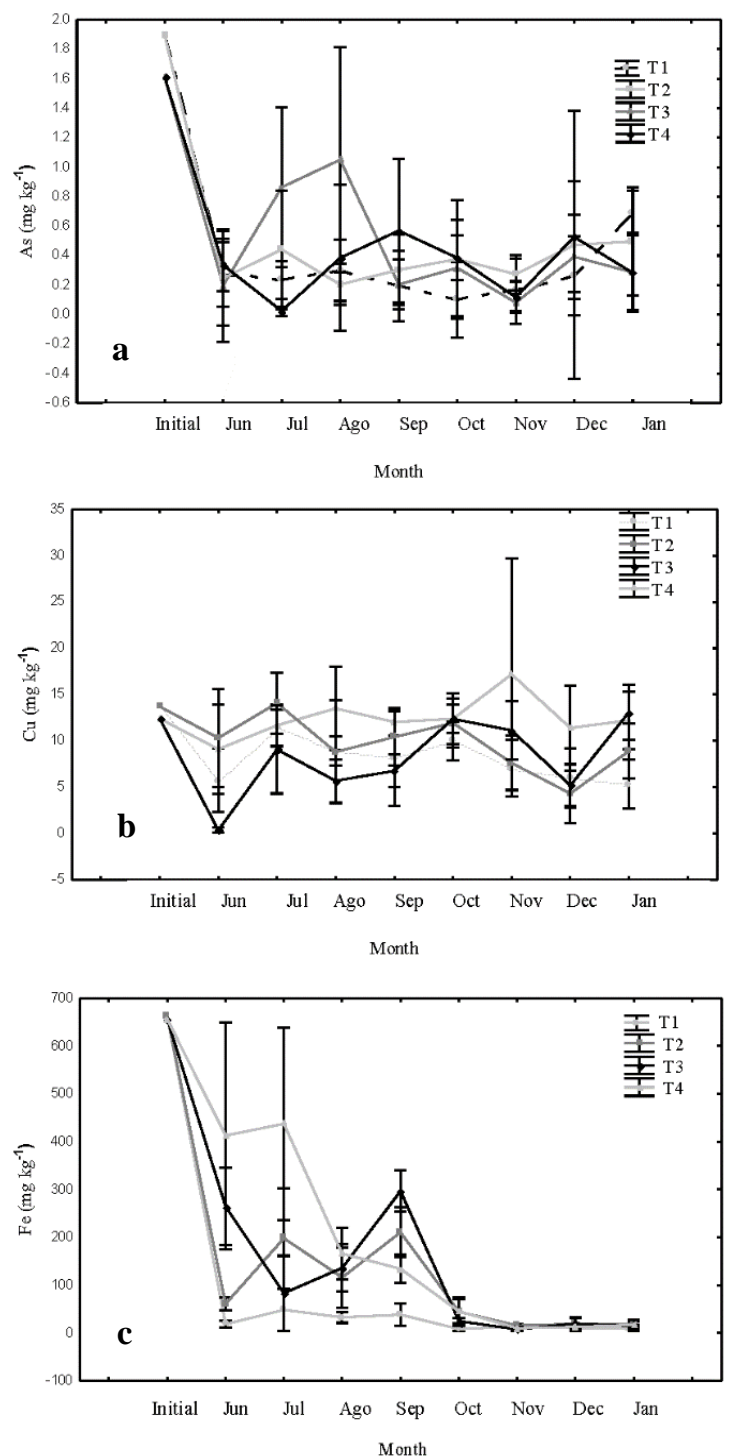

Figure 3. Variation in the concentrations of a) As, b) Cu and c) Fe, during the eight months of treatment. $T 1=$ waste sludge + soil $+P$. australis, $T 2=$ waste sludge + soil, $T 3=$ waste sludge $+P$. australis and T4 $=$ waste sludge, $(n=6)$, with a confidence interval of \pm 0.95 

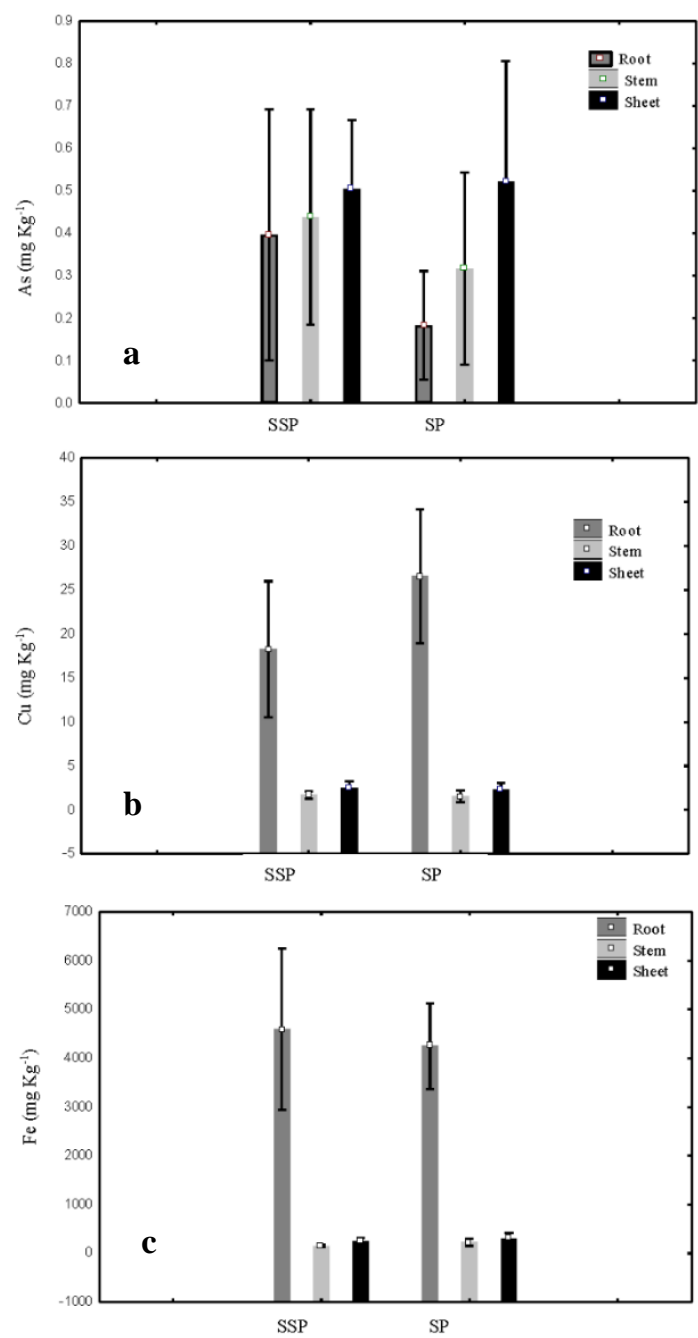

Figure 4. Concentration of the metals studied $\left(\mathrm{mg} \mathrm{kg}^{-1}\right)$ in root, stem and leaf of $P$. australis, a0 $A s, b) C u$ and c) Fe. Bars represent the means $\pm S D(n=6)$.

Table 5. Mean values of the bioconcentration factor and the translocation factor for the SSP and SP treatments between months

\begin{tabular}{|c|c|c|c|c|c|c|c|c|c|c|c|c|c|}
\hline \multirow{3}{*}{$\begin{array}{c}\text { Month } \\
\text { Sep }\end{array}$} & \multirow{3}{*}{$\begin{array}{c}\mathbf{T} \\
\mathrm{SSP}\end{array}$} & \multicolumn{6}{|c|}{ BCF } & \multicolumn{6}{|c|}{ BF } \\
\hline & & \multicolumn{2}{|c|}{ As } & \multicolumn{2}{|c|}{$\mathrm{Cu}$} & \multicolumn{2}{|c|}{$\mathrm{Fe}$} & \multicolumn{2}{|c|}{ As } & \multicolumn{2}{|c|}{$\mathbf{C u}$} & \multicolumn{2}{|c|}{$\mathbf{F e}$} \\
\hline & & 1.04 & $\pm 0.33^{* *}$ & 1.87 & \pm 1.23 & 7.77 & \pm 4.28 & 2.50 & \pm 1.80 & 0.32 & \pm 0.30 & 0.30 & \pm 0.53 \\
\hline Sep & SP & 1.07 & $\pm 0.46^{* *}$ & 2.32 & \pm 0.42 & 6.93 & \pm 1.69 & 5.25 & \pm 2.46 & 0.22 & \pm 0.10 & 0.15 & \pm 0.06 \\
\hline Jan & SSP & 0.34 & $\pm 0.18^{* *}$ & 1.41 & \pm 0.44 & 7.31 & \pm 3.95 & 9.15 & \pm 2.09 & 0.28 & \pm 0.15 & 0.11 & \pm 0.06 \\
\hline Jan & SP & 0.35 & $\pm 0.11^{* *}$ & 2.55 & \pm 1.10 & 7.53 & \pm 2.09 & 6.17 & \pm 3.38 & 0.13 & \pm 0.09 & 0.12 & \pm 0.06 \\
\hline
\end{tabular}

\section{Canonical correlation among plants and substrates}

Canonical correlation analysis was significant when we compared metal concentrations in plants versus metal concentration in the substrates $(R=0.9659$, 
$\left.\mathrm{Chi}^{2}=23.806, p=0.4727\right)$. Results showed a low correlation between metal concentrations in the plants versus the substrates (Table 6).
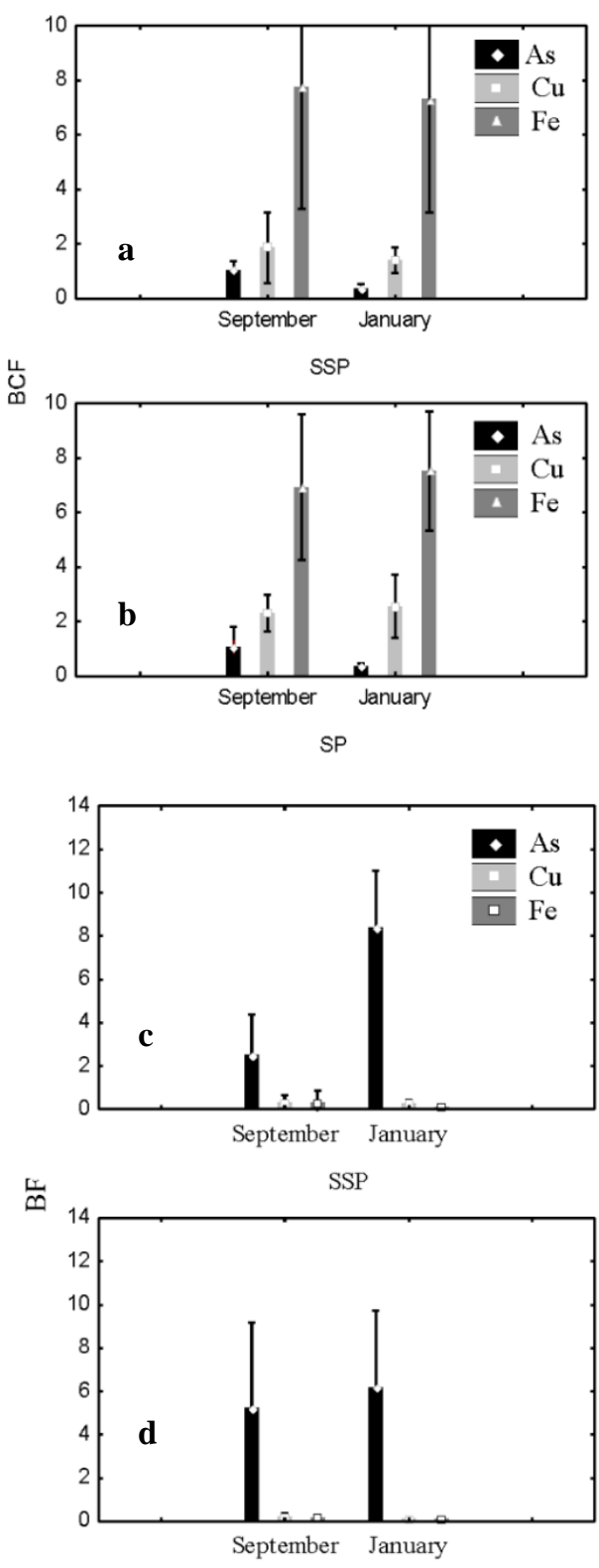

SP

Figure 5. Bioconcentration factor of the metals studied for September and January a) SSP treatment; b) SP treatment Translocation factor of metals in aerial part/roots of the plant per month, c) SSP treatment and d) SP treatment Average $(n=6)$

Table 6. Correlations between metals for plant and substrate

\begin{tabular}{l|c|c|c}
\hline \multirow{2}{*}{ Plants } & \multicolumn{3}{|c}{ Substrates } \\
\cline { 2 - 4 } & As & Cu & Fe \\
\hline As & 0.378599 & -0.218674 & -0.358279 \\
Cu & -0.632306 & 0.482277 & 0.547177 \\
Fe & -0.240246 & -0.224118 & -0.408420 \\
\hline
\end{tabular}




\section{Discussion}

\section{General characteristics of plants during the phytoremediation process using $P$. australis}

The optimal temperature range for $P$. australis plants is between $12-33{ }^{\circ} \mathrm{C}$, according to Cooper (1996). However, in this essay, the plants were exposed to ambient temperature of $03-42{ }^{\circ} \mathrm{C}$; exceeding by $8{ }^{\circ} \mathrm{C}$ the maximum value of said temperature. The temperature had an impact on the oldest leaves, which turned yellowish before wilting, a potential sign of heat stress (Yepes and Buckeridge, 2011). Although plants received consistent watering, the high temperatures affected the structure of substrates, leading to dehydration, compaction and low water availability (Paradelo, 2013).

\section{Substrate characterization}

$\mathrm{pH}$ was slightly acidic in every treatment, allowing the mobility and retention of As, $\mathrm{Cu}$ and $\mathrm{Fe}$, since most metals have better availability at acidic $\mathrm{pH}(\mathrm{As}, \mathrm{Ni}, \mathrm{Cu}, \mathrm{Fe}, \mathrm{Pb}$ ) (Wilson et al., 2010; Bolan et al., 2014). Ansari et al. (2014) indicate that $\mathrm{Cu}$ solubility increases at $\mathrm{pH}=5.5$. In this case, the initial and final $\mathrm{pH}$ of substrates led to low solubility of $\mathrm{Cu}$ and $\mathrm{Fe}$. Plants therefore showed a lower uptake of these metals (Pha et al., 2014); while As mobility increased at alkaline $\mathrm{pH}$, as shown by the $\mathrm{pH}$ increase in the substrates, from 6.75 to 8.36 (Bolan et al., 2011). pH increases in this essay did not show significant differences among treatments. This $\mathrm{pH}$ increase was due to organic matter (MO) breakdown, the content of $\mathrm{N}$ in the sewage sludge, and the rainfall events where water leached some cations, afterwards replaced by acidic elements, such as iron (Valentín-Vargas et al., 2014).

PR is another property affecting metal bioavailability by changing the state of ions. $\mathrm{PR}$ value in this essay was low, allowing $\mathrm{As}, \mathrm{Fe}$ and $\mathrm{Cu}$ to be available in the soil, at more soluble forms (Wilson et al., 2010; Bolan et al., 2014).

Heavy metal concentrations in initial substrates $(\mathrm{As}=1.61, \mathrm{Cu}=12.411$ and $\left.\mathrm{Fe}=656.365 \mathrm{mg} \mathrm{kg}^{-1}\right)$ did not exceed the values established by NOM-004SEMARNAT-2002 (As $=41$ and $\mathrm{Cu}=1500 \mathrm{mg} \mathrm{kg}^{-1}$ ). Nevertheless, it is important to minimize the metal content in sewage sludge, since metals have high capacity of bioaccumulation and biomagnification that increase their toxicity in trophic chains (Sabir et al., 2015; David et al., 2012).

Initial concentration of Arsenic in sewage sludge decreased from 1.61 to $0.345 \mathrm{mg} \mathrm{kg}^{-1}$, which is equal to $79.57 \%$ removal. Sludge $+P$. australis treatment had the highest removal percentage $(83.67 \%)$. Among the treatments of sludge and soil $+P$. australis; sludge and soil and sludge $+P$. australis there were no significant differences, indicating that $P$. australis, is not the only factor leading to Arsenic reduction in these treatments. These results were confirmed by the correlation analysis among plants and substrates, where we found a low correlation between the concentration of Arsenic in the substrate and Arsenic concentration in the plant $(\mathrm{R}=0.37)$. However, we found significant differences between the treatment of sludge and soil $+P$. australis mix, and the Sludge treatment. Therefore, the type of substrate and the presence/absence of $P$. australis allowed us to determine that Arsenic removal was impacted by the reductionoxidation potential; leaching during rainfall events and the mobility of Arsenic at the bottom of pots. The release of Arsenic particles depends on the formation of strong bonds between As particles and soil particles due to PR. In our case, soil aeration produced at low PR, led to a depletion of electron acceptors and the development of 
anoxic conditions forming iron oxides and oxygen hydroxides requiring reduction and dissolution, minimizing the uptake of arsenic from the sludge solution where it can be leached (Elekes, 2014; Punshon et al., 2017).

Initial $\mathrm{Cu}$ concentration in sewage sludge decreased from 12.411 to $9.437 \mathrm{mg} \mathrm{kg}^{-1}$, corresponding to an average removal percentage of $79.57 \%$. The treatment of sludge and soil $+P$. australis mix showed a higher removal percentage of $47.67 \%$. We observed significant differences among treatments, due to the type of substrate and the presence of $P$. australis. This is because alkaline $\mathrm{pH}$ affects trace elements like $\mathrm{Cu}$, in terms of solubility and bioavailability of the element, besides transportation at soil level (Avci and Deveci, 2013). These results coincide with the reports of Torres et al. (2010), who used similar treatments to remove $\mathrm{Cr}$ with vetiver, finding that the most effective treatment was the plant + sewage sludge + organic manure. Canonical correlation was $\mathrm{R}$ $=0.482$ when comparing $\mathrm{Cu}$ present in the substrates versus $\mathrm{Cu}$ present in the plants. This result explains the low removal percentage of $\mathrm{Cu}$.

Likewise, in case of Fe, initial concentration of the sewage sludge decreased from 656.36 to $91.90 \mathrm{mg} \mathrm{kg}^{-1}$, corresponding to an average removal percentage of 86.35 . Sludge and soil $+P$. australis mix treatment achieved the largest percentage of $\mathrm{Fe}$ removal (96.63\%). We found significant differences among the four treatments, showing that in the case of $\mathrm{Fe}$, the variables of plant and type of substrate (only sewage sludge or sludge and soil mix) had an impact on Fe removal. Canonical correlation indicated a low negative relation, when Fe decreased in the substrate, Fe increased in the plant $(\mathrm{R}=-0.408)$. However, the percentage of removal in substrates was high, maybe due to the leaching of Arsenic and the affinity to form iron sulfide under reduction conditions, such as the conditions found at test substrates. Other reasons might be a $\mathrm{pH}$ close to 7 and MO content, leading to low Fe solubility in the soil (Willscher et al., 2017).

\section{Accumulation of As, Cu, Fe in P. australis}

The test results showed significant differences among treatments (sludge and soil + $P$. australis mix and Sludge $+P$. australis) regarding Arsenic concentration in the stems and $\mathrm{Cu}$ concentration in the leaves. These results may imply that the type of substrate, $\mathrm{pH}, \mathrm{MO}$ and PR can have an impact on the affinity of these elements towards specific plant organs (Willscher et al. 2017). We found significant differences in metal concentrations along the time, for the sludge and soil $+P$. australis mix (As $=1.96$ to 0 . $65 \mathrm{mg} \mathrm{kg}^{-1}, \mathrm{Cu}=25.56$ to $14.47 \mathrm{mg} \mathrm{kg}^{-1}$ and $\mathrm{Fe}=5142.22$ to 722.23 ). The decrease in metal accumulation by the plants from September to January was due to the metals availability, depending on the different physical/chemical properties of substrates (Willscher et al., 2017; Avci and Deveci, 2013), and the variability of such properties, $(\mathrm{pH}, \mathrm{PR}, \mathrm{MO})$ as a consequence of the sludge addition before the first sampling in September. This addition modified $\mathrm{As}, \mathrm{Cu}$ and $\mathrm{Fe}$ concentrations, as well as the substrate characteristics (like it happened when mixing sewage sludge and soil), enabling better uptake of the three metals. The treatment sludge $+P$. australis, did not have any significant differences along the sampling months. We attributed this to the reports by Torres et al. (2010), indicating that the addition of the same substrate, in this case sewage sludge, does not imply a higher rate of metal uptake by the plants.

Plant tolerance to heavy metals like $\mathrm{As}, \mathrm{Cu}$ and $\mathrm{Fe}$ is due to the fact that these metals are transition metals with oxidizing capacity, as well as with an the capacity to reduce different biomolecules (Choppala et al., 2014). Therefore, these effects in the reduction- 
oxidation state of the cells enhanced due to the bonding reaction of these metals with biomolecules. This capacity can explain that the average concentration of $\mathrm{As}, \mathrm{Cu}$ and $\mathrm{Fe}$ in the organs of $P$. australis in dry weight. These elements, (As: 0.61, Cu: 11.56 and Fe: $1420.99 \mathrm{mg} \mathrm{kg}^{-1}$ ) were found within the typical ranges in plants reported by Larcher $(2003)=\mathrm{Cu}: 4-20$ but not typical for Fe: $2-700 \mathrm{mg} \mathrm{kg}^{-1}$. Although $\mathrm{Cu}$ is within the typical value range, it exceeds the value required by plants, just like Fe $\left(1-5 \mathrm{mg} \mathrm{kg}^{-1}\right.$ $\mathrm{Cu}$ and $100 \mathrm{mg} \mathrm{kg}^{-1} \mathrm{Fe}$ ).

$\mathrm{As}, \mathrm{Cu}$ and $\mathrm{Fe}$ accumulation was found in certain plant organs. We found accumulated arsenic in the leaves $\left(0.497 \mathrm{mg} \mathrm{kg}^{-1}\right)$. These results do not coincide with literature reports. $P$. australis belongs to the Poaceae family, characterized for having a great deal of roots promoting the accumulation of trace elements like As (Desjardins et al., 2018). According to Zhang et al. (2009) reports, there was an increase of As the roots of Phragmites communis (Trin., 1763).

Metals accumulated in the following order: root $>$ stem $>$ leaf. Higher concentration in the roots is due to the uptake of elements from the substrate, whereas the low concentration found in the stems may be due to their function as carriers of nutrients and minerals from the soil to aerial parts (Avci and Deveci, 2013).

$\mathrm{BCF}$ was determined in order to assess the accumulation efficiency of $\mathrm{As}, \mathrm{Cu}$ and $\mathrm{Fe}$ by $P$. australis. For $\mathrm{Fe}$ and $\mathrm{Cu}$ the values were greater than one, in sludge and soil $+P$. australis and Sludge $+P$. australis treatments, during the two sampling months. These data indicates that $P$. australis is a hyper-accumulating species of these two metals, following the criterion established by Baker and Brooks (1989). The discrimination analysis showed that there were no significant differences in the BCF of $\mathrm{Cu}$ among the sampling months. However, the Sludge $+P$. australis treatment had a slightly higher value, indicating that $\mathrm{Cu}$ uptake efficiency is better in soilless substrates. The reason is the changes in the substrate characteristics, such as the $\mathrm{pH}$ increase and the bonding affinity of metal particles to the substrate (Avci and Deveci, 2013). In the case of arsenic, BFC value changed along the time and the treatments. We observed significant differences in this metal among different months and treatments, which can be attributed to leaching, and may be also to the chemical similarity between $\mathrm{P}$ and As contents in the substrate, as mentioned by Yan et al. (2017); Escutia-Lara and LindigCisneros (2012). The roots were not able to uptake arsenic and the presence of other metals reduced the accumulation capacity of arsenic, coinciding with the reports of Desjardins et al. (2016).

$\mathrm{BCF}$ value for $\mathrm{Cu}$ (2.03) in P. australis was higher, compared to the reports from other species, including Malva parviflora (0.85), Datura stramonium L. (0.79), Citrullus colocynthis L. (0.84), Lycium shawii (Roem and Schult., 1990) (0.94) (Ibrahim et al., 2013). BCF value in Fe (7.38) was higher in Elodea canadensis (Michx.) (3.93), but it was lower, compared to Polytrychum commune (Hedw.) (0.9) and Spirogyra sp. (Link.) (10.25) (Busuioc et al., 2012). In both cases, $\mathrm{Cu}$ vales depended on the species, type of substrate, $\mathrm{pH}, \mathrm{PR}$ and metal bioavailability (Desjardins et al., 2018; Ezeudo, 2014).

The translocation factor determining the capacity of metals to move from the roots to aerial parts was higher for arsenic $(5.76>1)$, showing that Arsenic has great capacity to move into the leaves. This capacity can be the result of physiological factors of the species. $P$. australis has an extensive root system that can favor Arsenic permeability. Furthermore, this plant has the capacity to accumulate and transfer Arsenic from the roots to aerial parts (Yan et al., 2017). With regards to $\mathrm{Cu}(0.23)$ and $\mathrm{Fe}(0.17) \mathrm{TF}$ 
values were smaller than one, indicating that these metals are not easily taken to $P$. australis aerial parts. According to Padmavathiamma and Li (2009), immobilization may be due to metal scavenging by the vacuoles or by the cell wall in the roots, inhibiting the interaction with high molecular weight compounds of the cytoplasm.

\section{Conclusions and recommendations}

-The order of heavy metals removal by $P$. australis was the following: $\mathrm{Fe}>\mathrm{Cu}>\mathrm{As}$ $-\mathrm{pH}, \mathrm{PR}$ and $\mathrm{MO}$ affected the mobility and availability of $\mathrm{As}, \mathrm{Cu}$ and $\mathrm{Fe}$.

$-P$. australis is a tolerant species capable of accumulating large concentrations of $\mathrm{Fe}$ and

$\mathrm{Cu}$ in its organs, according to the following order: root $>$ stem $>$ leaf.

-The values of high $\mathrm{BCF}$ and low TF indicate that $P$. australis is a plant species that can

be used to phytostabilize substrates polluted with $\mathrm{Fe}$ and $\mathrm{Cu}$.

In the process of phytoremediation metal removal was observed not attributed to the plants so it may be appropriate to carry out leaching tests such as the Tessier scheme, in the waste sludge, soil and mixture in order to identify if it is because of these processes that decrease the concentration of metals in the waste sludge.

\section{REFERENCES}

[1] Ansari, A, Singh, S., Gill, R., Lanza, G. Newman, L. (2014): Phytoremediation Management of Environmental Contaminants. - Springer, Berlin.

[2] Avci, H., Deveci, T. (2013): Assessment of trace element concentrations in soil and plants from cropland irrigated with wastewater. - Ecotoxicol. Environ. Saf. 98: 283-291.

[3] Bake, A. J. M., Brooks, R. R. (1989): Terrestrial higher plants which hyperaccumulate metallic. - Biorecovery1: 81-126.

[4] Bolan, N., Park, J. H., Robinson, B., Naidu, R., Huh, K. Y. (2011): Phytostabilization. A green approach to contaminant containment. - Adv. Agron. 112: 145-204.

[5] Bolan, N. S., Kunhikrishnan, A., Thangarajan, R., Kumpiene, J., Park, J., Makino, T., Kirkham, M. B., Scheckel, K. (2014): Remediation of heavy metal(loid)s contaminated soils - To mobilize or to immobilize? - J. Hazard. Mater. 266: 141-166.

[6] Busuioc, G., David, I., Mihaela, S., Iliescu, N. (2012): Evaluation of capacity for bioaccumulation of some heavy metals in three aquatic plants species. - Water Resources and Wetlands 14: 220-223.

[7] Castañeda, A., Flore, H., Velazco, R., Martínez, M. (2011): Efectos de la aplicación de lodos orgánicos o biosólidos generados en el tratamiento de las aguas residuales domésticas sobre el suelo y la productividad de maíz forrajero en los Altos de Jalisco, México. - In: Spring, U., Sánchez, C., Miranda, M., Pérez, R., Domínguez, A., Garatuza, J., Watts, C. (eds.) Retos de la investigación del agua en México. UNAM, México, D. F., pp. 227-237.

[8] Chandra, P. V. (2013): Suitability of Ricnus communis L. cultivation for phytoremediation of fly ash disposal sites. - Ecol Eng. 57: 336-341.

[9] Choppala, G., Saifullah., Bolan, N., Bibi, S., Iqbal, M., Rengel, Z., Kunhikrishnan, A., Nanjappa, A., Sik, O. (2014): Cellular mechanisms in higher plants governing tolerance to cadmium toxicity. Crit. Rev. - Plant Sci. 33: 374-391.

[10] CONAGUA, Comisión Nacional de Agua (2011): Inventario Nacional de plantas municipales de potabilización y de tratamiento de aguas residuales en operación, diciembre 2013. - SEMARNAT, México. 
[11] CONAGUA, Comisión Nacional de Agua (2015): Inventario Nacional de plantas municipales de potabilización y de tratamiento de aguas residuales en operación, diciembre 2015. - SEMARNAT, México.

[12] Cooper, P. (1996): Reed Beds and Constructed Wetlands for Wastewater Treatment. WRc, Severn Trent Water. - Marlow, Bucks, UK.

[13] CRA, Comisión de Regulación de Agua Potable y Saneamiento Básico. (2000): Reglamento técnico del sector de agua potable y saneamiento básico RAS - 2000 Sección II, Título E, Tratamiento de aguas residuales. - Bogotá, D. C. Colombia.

[14] David, L., Matache, M., Tudorache, A., Chisamera, G., Rozylowicz, L., Lucian, G. (2012): Food chain biomagnification of heavy metals in samples from the lower prut foodplain natural park. Environ. - Eng. Manag. J. 11(1): 69-73.

[15] Desjardins, D., Pitre, F. E. E., Nissim, W. G. G., Labrecque, M. (2016): Differential uptake of silver, copper and zinc suggests complementary species-specific phytoextraction potential. - Int. J. Phytorem. 18: 598-604.

[16] Desjardins, D., Brereton, J. B. N., Marchand, L., Brisson, J., Pitre, E. F., Labrecque, M. (2018): Complementarity of three distinctive phytoremediation crops for multiple-trace element contaminated soil. - Science of the Total Environment. 610-611: 1428-1438.

[17] Elekes, C. (2014): Eco-Technological Solutions for the Remediation of Polluted Soil and Heavy Metal Recovery. - In: Hernandez, M. (ed.) Environmental Risk Assessment of Soil Contamination. InTech, London.

[18] Escutia-Lara, Y. y Lindig-Cisneros, R. (2012): Dinámica de Phragmites australis y Schoenoplectus americanus en respuesta a la adición de fósforo y nitrógeno. - New Phytol 181: 777-794.

[19] Ezeudo, V. C. (2014): Mobility of heavy metals from the University of Nigeria sewage sludge disposal site to the surrounding soils and plants. - Dissertation, University of Nigeria.

[20] Ibrahim, M., Alsahli, A., El-Gaaly, G. (2013): Evaluation of phytoremediation potential of six wild plants for metal in a site polluted by industrial wastes: a field study in Riyadh, Saudi Arabia. - Pak J. Bot. 42(2): 571-576.

[21] Jing, X., Guojun, Y., Donghui, L., Yiran, L., Mai, L., Zhiqiang, Z., Peng, W. (2017): Effects of wastewater irrigation and sewage sludge application on soil residues of chiral fungicide benalaxyl. - Environ. Pollut. 224: 1-6.

[22] Larcher, W. (2003): Physiological Plant Ecology: Ecophysiology and Stress Physiology of Functional Groups. 4th Ed. - Springer, Berlin.

[23] Norma Oficial Mexicana NOM-004-SEMARNAT (2002): Secretaria del Medio Ambiente y Recursos Naturales. Protección ambiental. Lodos y Biosólidos Especificaciones y límites máximos permisibles de contaminantes para su aprovechamiento y disposición final. - Viernes 15 de agosto de 2003.

[24] Padmavathiamma, P., Li, L. (2009): Phytoremediation of metal - contamined soil in temperature humid regions of British Columbia, Canada. - Int. J. Phytoremediation 11: 575-590.

[25] Paradelo, R. (2013): Utilización de materiales compostados en la rehabilitación potencial de espacios afectados por residuos mineros y suelos de mina. - Boletín Geológico y Minero. 124(3): 405-419.

[26] Pha, T., Minh, D., Xuan, D., Duc, L. (2014): Growth and absorbance of heavy metals of reed plants (Phragmites australis) in soil after mineral mining in Thai Nguyen Province of Vietnam. - Res. J. Agric. \& Biol. Sci. 9(8): 1990-6145.

[27] Punshon, T., Jackson, P. B., Meharg, A. A., Warczack, T., Scheckel, K., Guerinot, M. L. (2017): Understanding arsenic dynamics in agronomic systems to predict and prevent uptake by crop plants. - Sci. Total Environ. 581-582: 209-220.

[28] Rojas, R., Mendoza, L. (2012): Utilización de biosólidos para la recuperación energética en México. - Producción + limpia 7: 74-94. 
[29] Sabir, M., Waraich, E. A., Hakeem, K. R., Öztürk, M., Ahmad, H. R., Shahid, M. (2015): Phytoremediation, Soil Remediation and Plants. - Elsevier Inc., Amsterdam.

[30] Salema, B., Laffraya, X., Ashoour, A., Ayadib, H., and Aleyaa, L. (2014): Metal accumulation and distribution in the organs of Reeds and Cattails in a constructed treatment wetland (Etueffont, France). - Ecol. Eng. 64: 1-17.

[31] SAS Institute. (2002): SAS System for Windows, Release 9.0. - SAS Institute, Cary, NC.

[32] Torres, D., Cumana, A., Torrealba, O., Posada, D. (2010): Uso del vetiver para la fitorremediación de cromo en lodos residuales de una tenería. - REMEXCA 11(21): 175188.

[33] Valentín-Vargas, A., Root, R. A., Neilson, J. W., Chorover, J., Maier, R. M. (2014): Environmental factors influencing the structural dynamics of soil microbial communities during assisted phytostabilization of acid-generating mine tailings: a mesocosm experiment. - Sci. Total Environ. 500: 314-324.

[34] Wilson, S. C., Lockwood, P. V., Ashley, P. M., Tighe, M. (2010): The chemistry and behaviour of antimony in the soil environment with comparisons to arsenic: a critical review. - Environ. Pollut. 158: 1169-1181.

[35] Willscher, S., Jablonski, L., Fona, Z., Rahmi, R., Wittig, J. (2017): Phytoremediation experiments with Helianthus tuberosus under different $\mathrm{pH}$ and heavy metal soil concentrations. - Hydrometallurgy 168: 153-158.

[36] Yan, X., Liu, Q, Wang, J., Liao, X. (2017): A combined process coupling phytoremediation and in situ flushing for removal of arsenic in contaminated soil. - J. of Environl. Sci. 57: 104-109.

[37] Yepes, A., Buckeridg, M. (2011): Respuestas de las plantas ante los factores ambientales del cambio climático global - revisión. - Colombia Forestal. 14(2): 213-232.

[38] Zhang, M., Cui, L., Sheng, L., Wang, Y. (2009): Distribution and enrichment of heavy metals among sediments, water body and plants in Hengshuihu Wetland of Northern China. - Ecol. Eng. 35: 563-569. 